\title{
Gen action for yield and yield component under salinity stress in bread wheat. - a review.
}

\author{
Elshazly, I.F.O. ${ }^{1 *}$, T.M. Elameen ${ }^{1}$ and A.G.A. Khaled ${ }^{2}$ \\ ${ }^{I}$ Department of Genetics, Faculty of Agriculture, South Valley University, Qena, 83523, Egypt. \\ ${ }^{2}$ Department of Genetics, Faculty of Agriculture, Sohag University, Sohag, Egypt.
}

\begin{abstract}
A salinity stress problem is defined as a condition where the salts in solution within the crop root zone accumulate in high concentrations, which decrease crop yield. Bread wheat (Triticum aestivum. L) is a moderate to salinity tolerance crop Salinity susceptibility index (SSI) become widely used by researchers to identify sensitively and resistant wheat genotypes and increase wheat yield is to improve the salinity tolerance of genotypes. Heterosis represents the percentage of augmenting or decrease in the mean value of the F1 hybrids over their mid-parents' value. The heterosis represents the percentage of increase or decrease in the mean value of F1 hybrid over a better parent. Knowledge of broad-sense heritability (h2 b.s), narrow-sense heritability (h2 n.s), general combining ability (GCA), and specific combining ability (SCA) is useful in the choice of parental genotypes. Combining ability studies assist in the identification of parents with greater GCA values and parental combinations with greater SCA values. High heritability values of the type, which give salinity tolerance in wheat, fixed that a major advance in salinity tolerance may be possible through selection by the order of high selection pressure. The additive and nonadditive gene action played a major role in controlling for traits of wheat under normal conditions and salinity stress.
\end{abstract}

Keywords: Combining ability; Heritability; Salinity stress; Wheat.

\section{Introduction}

Wheat (Triticum aestivum L.) is taken into account one among the foremost important strategic cereal crops in Egypt and therefore the world. It is the important stable food of about Two billion people (36\% of the population's world); provides nearly $20 \%$ of the food calories consumed globally and $55 \%$ of the carbohydrates (Breiman and Graur, 1995). It

\footnotetext{
*Corresponding author: Ibrahim F. O. Elshazly Email: ibrahim.fathi@agr.svu.edu.eg Received: January 15, 2021; Accepted: January 30, 2021; Published online: February 2, 2021. (C) Published by South Valley University. This is an open access article licensed under (C)(이이
}

is the main cereal crop of rabi season and is grown in almost parts of Egypt. Most of the currently cultivated wheat varieties belong to hexaploidy wheat (Triticum aestivum L.), which is understood as common bread wheat and valued for bread making. Through the last 20 years, the global wheat average varied between 207 and 227 million hectares (Ljubicic et al., 2014). In Egypt's total wheat production of grain reached about nine million tons resulted from 1.430 million ha with 6.30 ton/ha, while the consumption of wheat grains is about 15 million tons (Anonymous, 2016). In spite, the high increase in production of wheat in Egypt that reached 8.8 million ton produced from 1.34 
million ha with 6.57 ton/ha (FAO, 2017), 13 million tons of wheat imports (FAO, 2020). this gab still there between production and consumption. Yield potential losing by individual abiotic stresses with values of $20 \%$ for salinity, $17 \%$ for drought $40 \%$ for heat tolerance, $15 \%$ for low temperature, and $8 \%$ for other factors Ashraf and Harris (2005).

Salinity stress is one of the major factors responsible for less yield and restricted economic utilization of land resources both in arid and semi-arid regions of the World severe salinity problems (Ghassemi et al., 1995; Arzani and Mirodjagh, 1999; Arzani, 2008). Over 800 million hectares of land are saline affected throughout the world (Munns, 2005). For example, $33 \%$ of the farmland, which comprises only $3 \%$ of total acreage in Egypt, is already salinized due to low precipitation $(<25 \mathrm{mM}$ annual rainfall) and irrigation with saline water (Ghassemi et al., 1995). Ragab (2001) found that, there was a progressive and significant increase in salt soil values as the salinity of irrigation water increases. it is necessary to increase wheat production for raising the wheat grain yield. additionally, the most efficient way to increase wheat yield is to improve the salinity tolerance of wheat genotypes (Pervaiz et al., 2002). Salinity tolerant crops varieties can be developed by conventional methods will the genetic variation for salinity tolerance.

\section{Effect of salinity stress}

Salinity problem is defined as a condition where the salts in solution within the crop root zone accumulate in high concentrations which decrease crop yield (Ayers and Westcot, 1985). Salts in the soil water solution can reduce evapotranspiration by making soil water less available for plant root extraction (Allen et al., 1998). In spite of, under salinity conditions, plants are able to partially compensate for low osmotic potential of the soil water by building up higher internal solute contents (Allen et al.,
1998). That the effect of salt and water stress are generally additives in their impacts on crop evapotranspiration (Shalhevet, 1994). Under saline conditions, plant growth is usually reduced by reducing the rate of leaf elongation, enlargement and cells division in the leave (Allen et al., 1998). Bread wheat (Triticum aestivum L.) is a moderate to salinity tolerance crop (Maas and Hoffman, 1977). Saline stresses are the major environment that great affect the plant productivity. (Arzani and Mirodjagh, 1999). Salinity susceptibility index (SSI) become widely to use by researchers for identify sensitively and resistant wheat genotypes and increase wheat yield is to improve the salinity tolerance of genotypes (Clarke et al., 1992; Pervaiz et al., 2002).

El-Sayed et al. (2002) 10 genotypes were SSI less than unity and are relatively tolerant to salinity stress based on 100-kernels weight, such as, genotypes. Regarding SSI, 11 genotypes were values less than unity and relatively tolerant to saline stress Pakniyat et al. (2003). Similarity, Mahar et al. (2003) found that long spike, tillers and grain weight were high significant. The experiment was conducted at three different locations having saline of 4, 6.5 and $7.8 \mathrm{dSm}^{-1}$. Oraby et al. (2005) reported that the longest genotype in spike length was (8.18 $\mathrm{cm}$ ) had significantly longer spike and the shortest was with value of $3.13 \mathrm{~cm}$ under salinity soil. SSI results showed that spike length genotypes were tolerant to salinity stress and had SSI values of $0.47,0.73$ and 0.84 . El-Hendawy et al. (2005) exhibited that numbers of tiller were affected. Spikelet's number on the main stem was decreased much more with salinity than spike length, grain number and 1000-grain weight at maturity. The Egyptian genotypes Sakha 8 and Sakha 93 and the Indian genotype Kharchia were recorded as the most tolerant to salinity stress. Additionally, in saline tolerant with growth stages was showed for Gemmeza 7, Sids 1 and Westonia. Drysdale and Sakha 69 had 
ranked as moderate tolerant. The remaining genotypes showed rock bottom tolerance to salinity in the least growth stages. Similarity, that wheat genotypes Shakha 93, Shakha 8 can be selected to grow under salinity stress conditions (Hamam and Negim, 2014; Tharwat et al., 2020). All was agreed with that an increase in tiller number/plant and spikelet number/spike will improve the salinity tolerance of wheat genotypes in breeding programs. AbuEl-lail et al. (2014) evaluated 280 genotypes under salinity conditions were screened by germination. under salinity with different levels of $\mathrm{NaCl}$ in vitro. Gadallah et al. (2017) reported that the results of SSI showed that there were variations among the 16 genotypes of wheat cultivars for their response to saline stress. Sakha 93 and Sahel 1 exhibited the lowest value of SSI (0.69 and 0.71), respectively. The genotypes Sids 1, Shandweel 1, Misr2 and Misr 1 had moderate tolerant to saline stress. Additionally, Gemmiza 9 and Gemmiza 11 were the most sensitive for salinity stress. Similarity, Tharwat et al. (2020) reported that 6 parental genotypes were relatively stress tolerant parents with the (SSI) values of $(0.90,0.95,0.86,0.93$, 0.94 and 0.93). Regarding $11 \quad F_{1}$ crosses combinations were relatively tolerant to saline tolerance. The six parents were tolerant to salinity transmitted their genes controlling salinity tolerance to their hybrids. Consequently, these crosses could be respectable promising populations for cultivating under salinity tolerance. 11 bread wheat genotypes were studied under saline stress by (Elshafei et al., 2019). Owing to the differences in the levels of saline at the 2 site, significant differences were reported between the tested genotypes for each trait. L2 and L4 Lines recorded that highest grain yields.

\section{Heterosis}

Heterosis represents the percentage of augment or decrease in the mean value of the $F_{1}$ hybrids over their mid parents' value. While, heterosis represents the percentage of increase or decrease in the mean value of $F_{1}$ hybrid over better parent. Okasha and Hussein (2017) reported that positively and significant heterosis over mid parent for yield and its components had manifested by crosses P1xP2, P1xP3, $\mathrm{P} 1 \mathrm{xP} 4, \mathrm{P} 1 \mathrm{xP} 5$ and $\mathrm{P} 2 \mathrm{xP5}$ under normal and salinity stress conditions. Khaled et al. (2020) studied those three studied traits under Favorable, salinity stress and their combined data for heterosis of all crosses over mid parents (H M.P \%) and better parent (H B.P \%) for the results for Days to 50\% Tipping of heterosis over mid parents indicated that 4 crosses were the best significant negative heterotic values under Favorable conditions. While, 4 hybrids under salinity stress. The results over better parent for the same trait showed that $2 \mathrm{~F}_{1}$ crosses the best significant negative heterotic values under Favorable conditions. While, 8 hybrids were the best under salinity stress. Concerning to spike length, the estimates of heterosis over mid parents indicated that the three crosses had the highest positive heterotic values under Favorable condition. On the other hand, 6 best heterotic crosses under salinity stress conditions. The results of better parent showed that the best three crosses were significant heterotic under Favorable condition. Meanwhile, 5 under salinity stress. The best desirable heterotic cross was $\left(\mathrm{P}_{2} \mathrm{xP}_{7}\right)$ with heterotic under salinity stress for No. of spikelets/spike. The heterotic values over better parent exhibited that 2 crosses had the desirable significant positive heterotic under Favorable. Moreover, 3 crosses under salinity stress. BABU et al. (2005) exhibited that high mean values for all the traits taken for study except 100-grain weight and also had high standard heterosis percentage for days to $50 \%$ flowering, productive tillers plant in rice Under Salinity Affected Environments. 


\section{Genetic Parameters}

Afiah and Darwish (2002) studied the combining ability effects for plant height in wheat under rainfed and salinity stresses. GCA/SCA ratio was much higher than unity under drought stress (indicating predominance of additive) and less than unity under salinity conditions (indicating predominance of nonadditive).

Kulshreshtha and Singh (2011) studied that combining ability, heritability and gene action estimates for yield under normal and saline irrigated conditions were studied using $8 \times 8$ diallel crosses in bread wheat. Each additive and non-additive gene action were recorded important in the inheritance of yield under saline as well as normal irrigation conditions. Under normal conditions all the traits were showed to be governed by non -additive gene action with low heritability, whereas under salinity stress, plant height and spikelets/spike cleared high heritability with importance of additive effects. One other hand traits under salinity stress exhibited medium to low heritability with nonadditive gene action. Additive genetic effects were significantly for plant height and tillers/plant under sodium chloride for salinity. the results cleared that heritability of narrow sense ( $h^{2}$ n.s) estimates ranged from 0 to $51 \%$, whereas heritability of broad sense $\left(h^{2}\right.$ b.s) estimates ranged from 25 to $84 \%$ for the studied traits reported by Munir et al. (2013). Also, Marzooghian et al. (2014) found that additive effects were present for plant height at 125 $\mathrm{mMNaCl}$ and for $\mathrm{KNa}-1$ at $250 \mathrm{mMNaCl}$. Furthermore, each additive effect and additive by additive epistasis governed the control of plant height at the non-salinity condition. Broad sense heritability was High and narrow sense heritability was moderate were showed for most of the measured traits under different salinity levels. (GCA) for plant height, No. of tillers/plant, stem diameter, 100-grain weight and Grain yield/plant was highly significant under salinity stress, normal. Furthermore, Mean square of (SCA) for plant height, No. of tillers/plant stem diameter, 100-grain weight and Grain yield/plant was highly significant under normal condition, but under salinity stress was plant height for Grain yield/plant and significant for No. of tillers/plant exhibited by Tharwat et al. (2020). Also, they estimated that $\left(\sigma^{2} \mathrm{~A}\right)$ for plant height, stem diameter and 100-grain weight were higher than those of $\left(\sigma^{2} \mathrm{D}\right)$ under normal condition and salinity stress. Moreover, the $\left(\sigma^{2} D\right)$ for Grain yield/plant were higher than those of $\left(\sigma^{2} \mathrm{~A}\right)$ under normal condition and salinity stress. In addition, the values of $\left(h^{2} b\right.$. s\%) for plant height were $(92.25,79.29$ and $84.56 \%)$. While, the estimated values of $\left(\mathrm{h}^{2} \mathrm{n}\right.$. s\%) were (77.81, 79.09 and $67.75 \%$ ) under normal and salinity conditions. It could be concluded that the additive and non - additive gene action played a major role in controlling for plant height and Grain yield/plant under normal condition and salinity stress.

The results of days to 50\% Tipping exhibited that the mean squares of (GCA) and (SCA) for days to $50 \%$ Tipping was highly significant under Favorable, salinity stress Mean square of (GCA) for Spike length was highly significant under Favorable, salinity stress and combined data. Furthermore, mean square of (SCA) for Spike length was highly significant under Favorable condition, significant under salinity stress. Concerning to mean square of (GCA) and (SCA) for No. of spikelets/spike were highly significant under Favorable, salinity stress. Confirming the important role of all types of gene action in the inheritance of this traits. Where, the genetic parameters obtained from the analysis of the half diallel mating design could be divided to additive $\left(\sigma^{2} \mathrm{~A}\right)$ and non-additive $\left(\sigma^{2} \mathrm{D}\right)$ genetic variances assuming that there is no epistasis. In addition, the values of heritability in broad sense ( $h^{2}$ b.s $\left.\%\right)$ estimates the amount of genetic variance included additive and non- 
additive relative to phenotypic variance that results obtained by Khaled et al. (2020).

\section{Genotypic and phenotypic Correlation}

The estimates of genotypic and phenotypic correlations between economic traits in wheat are of great important to plant breeding (ElSherbieny, 1996). El Ameen et al. (2013) reported that positive and significant correlations were cleared for 1000-grian weight, number. of kernels/spike and spike length in $\left(\mathrm{F}_{3}\right)$ but not in the second selection's cycle under drought and salinity conditions.

Tharwat et al. (2020) exhibited that genotypic correlation for plant height was highly significant with No. of tillers/plant, No. of spikelets/spike, spike length, stem diameter, and grain yield/plant under salinity condition. However, genotypic correlation for stem diameter was highly significant with 100-grain weight under each environment. Additionally, the genotypic and phenotypic correlations were highly significant between No. of tillers/plant and grain yield/plant under each environment.

\section{Conclusion}

Values of heritability type which give salinity stress in Triticum aestivum $\mathrm{L}$. fixed that a major advance in salinity tolerance could be possible through selection programs by the order of high selection pressure. It could be concluded that the additive and non additive gene action played a major role in controlling for traits of wheat under normal condition and salinity stress.

\section{References}

Abu-El-lail F.F.B., Hamam, K.A., Kheiralla, K.A., El-Hifny, M.Z. (2014). 'Salinity tolerance in 280 genotypes of two-rows Barley.', Egyptian Journal of Plant Breeding, 18 (2) pp. 331- 345.

Afiah, S.A.N., Darwish, I.H.I. (2002). 'Combining ability analysis and heterosis in relation to salinity and drought stress for yield and its attributes of breed wheat.', $J$. Agric. Sci. Mansoura Univ., 27, pp. 80338049.

Allen, R.G., Pereira, L.S., Raes, D., Smith, M. (1998): 'Crop evapotranspiration. Guideline for computing crop water requirements.', FAO No56.

Anonymous, (2016). 'Wheat production and consumption', Economic Affairs Sector. ARC, Giza, Egypt.

Arzani, A. (2008). 'Improving salinity tolerance in crop plants: a biotechnological view.', In Vitro Cell Dev. Biol. Plant, 44, pp. 373-383.

Arzani, A., Mirodjagh, S.S. (1999). 'Response of durum wheat cultivars to immature embryo culture, callus induction and in vitro salt stress.', Plant Cell Tiss. Org. Cult., 58, pp. 67-72.

Ashraf, M., Harris, P.J.C. (2005). 'Abiotic Stresses Plant Resistance through Breeding and Molecular Approaches.', Food Products Press, an imprint of The Haworth Press, Inc., Binghamton, New York, USA, pp. 3-15.

Ayers, R.S., Westcot, D.W. (1985). 'Water quality for agriculture.', FAO Irrigation and Drainage Paper 29, FAO, Rome.

BABU, S., YOGAMMENAKSHI, P., SHEEBA, A., ANBUMALARMATHI, J., RANGASAMY, P. (2005). 'Heterosis in Rice Under Salt Affected Environments.', Madras Agric. J. 92 (7-9), pp. 369-374.

Breiman, A., Graur, B. (1995). 'Wheat Evolution.', Israel Journal of Plant Science, 43, pp. 85-98.

Clarke, J.M. De Pauw, R.M., Townley-Smith, T.M. (1992). 'Evaluation of methods for quantification of drought tolerance in wheat.', Crop Sci., 32, pp. 728-732.

El Ameen, T., Hossain, A., Teixeira da Silva, J.A. (2013). 'Genetic Analysis and Selection for Bread Wheat (Triticum aestivum L.) Yield and Agronomic Traits under Drought Conditions.', International Journal of Plant Breading. 7(1), pp. 61-68. 
El-Hendawy S.E., Hu, Y., Yakout, G.M., Awad, A.M., Hafiz, S.E., Schmidhalter, U. (2005). 'Evaluating salt tolerance of wheat genotypes using multiple parameters.', Europ. J. Agronomy, 22, pp. 243-253.

El-Sayed, A.M., Hamada, M., El-Sayed, A.H., Kirkwood, R.C.I. (2002). 'Response of barley, wheat and maize to salinity stress seed germination, plant growth, water relations and yield.', J. of Environmental Res. Zagazig Univ. Egypt. 4, pp. 88-104.

Elshafei, A.A., Afiah, S.A., Al-Doss, A.A., Ibrahim, E.I. (2019). 'Morphological variability and genetic diversity of wheat genotypes grown on saline soil and identification of new promising molecular markers associated with salinity tolerance', JOURNAL OF PLANT INTERACTIONS, 14(1), pp. 564-571.

El-Sherbieny, G.A.R. (1996). 'THE RELATIVE IMPORTANCE OF ADDITIVE AND NONADDITIVE GENETIC VARIANCES FOR BREEDING NEW VARIATIES OF WHEAT (Triticum Spp.L.).', Thesis Ph.D. in Department of Genetics, Fac. Agric. Mansoura Univ.

FAO (Food and Agriculture Organization). (2017). 'Statistics Division. ', United States.

FAO (2020). 'Food and Agricultural Organization of United Nations.', GIEWS Country Brief Egypt. https://www.fao.org/giews.

Gadallah, M.A., Milad, S.I., Mabrook, Y.M., Abo Yossef, A.Y., Gouda, M.A. (2017). 'Evaluation of Some Egyptian Bread Wheat (Triticum aestivum) Cultivars under Salinity Stress.', ALEXANDRIA SCIENCE EXCHANGE JOURNAL,38(2).

Ghassemi, F. Jakeman, A.J., Nix, H.A. (1995). 'Salinization of land and water resources: human causes, management and case studies. ', CABI/ Univ. New South Wales.

Hamam K.A. and Negim O. (2014): Evaluation of wheat genotypes under saline water irrigation. Annals of agriculture science. 59(2), 165-176.

Khaled, A.G.A., Elameen, T.M., Elshazly, I.F.O. (2020). 'Heterosis and Combining Ability under Favorable and Salinity Stress in Egyptian Bread Wheat.', Asian Journal of Research and Review in Agriculture, 2(1), pp. 35-51. Retrieved from https://globalpresshub.com/index.php/AJRR A/article/view/857

Kulshreshtha, N., Singh, K.N. (2011). 'Combining ability studies in wheat (Triticum aestivum L.) for genetic improvement under salt stress.', J. Wheat Res., 3(2): pp. 22.

Ljubicic, N., Petrovic, S., Dimitrijevic, M., Hristov, N., Vukosavljev, M., Sreckov, Z. (2014). 'Diallel analysis for spike length in winter wheat.', Turkish Journal of Agricultural and Natural Sciences, 2, pp.1455-1459.

Maas, E.V., Hoffman G.J. (1977). 'Crop salt tolerance - current assessment.', Journal of the Irrigation and Drainage Division of the American Society of Civil Engineering. 103, pp. 115-134.

Mahar, A.R., Memon, J.A., Abro, S.A., Hollington, P.A. (2003). 'RESPONSE OF FEW NEWLY DEVELOPED SALTTOLERANT WHEAT LANDRACR SELECTIONS UNDER NATURAL ENVIRONMENTAL CONDITIONS.', Pak.

J. Bot., 35(5), pp. 865-869.

Marzooghian, A., Moghaddam, M., Toorchi, M., Shakiba, M.R. (2014). 'Investigation of genetic structure and gene action in bread wheat affected by salt stress.', International Journal of Biosciences $|I J B|$. 5(6), pp. 173181.

Munir, A., Iqbal, M., Shahzad, A., Asif, M., Sajad, M. (2013). 'Genetic Analysis of Yield and Yield Contributing Quantitative Traits in Bread Wheat Under Sodium Chloride 
Salinity.', Journal of Agricultural Science. $5(6)$.

Munns, R. (2005). 'Genes and salt tolerance: bringing them together.', New Phytologist, 167, pp. 645-663.

Okasha, S.A., Hussein, M.A. (2017). 'COMBINING ABILITY AND HETEROSIS ESTIMATES OF SOME WHEAT GENOTYPES UNDER SALINITY STRESS CONDITIONS.', Egypt. J. Plant Breed. 21(4), pp.769- 795.

Oraby, H.F., Ransom, C.B., Kravchenko, A.N., Sticklen, M.B., (2005). 'Barley HVA1 gene confers salt tolerance in R3 transgenic oat.', Crop Sci., 45(6), pp. 2218-2227.

Pakniyat, H., Kazemipour, A., Mohammadi, G.A. (2003). 'Variation in salt tolerance of cultivated (Hordeum vulgare L.) and wild (H. spontaneum C. Koch) barley genotypes from Iran.', Iran. Agric. Res., 22(1), pp. 4562. (C.F.PI. Breeding Abst. Vol.74 NO. 7: p, 1142).

Pervaiz, Z., Afzal, M., Xi, S., Xiaoe, Y., Ancheng, L. (2002). 'Physiological parameters of salt tolerance in wheat.', Asian J. Plant. Sci., 1, pp. 478-481.

Ragab, A.A.M. (2001). 'Physical properties of some Egyptian soils.', Ph.D. Thesis, Fac. of Agric, Cairo Univ, Egypt.

Shalhevet, J. (1994). 'Using water of marginal quality for crop production Major. issues Review article.', Agricultural Water Management. 25, pp. 233-269.

Tharwat, E.A.M., Khaled, A.G.A., Elshazly, I.F.O. (2020). 'Genetic Analysis of Eight Parents and their 28 Hybrids under Salinity Tolerance in Bread Wheat.', Asian Journal of Research in Biosciences, 2(1), pp. 37-48. Retrieved from https://globalpresshub.com/index.php/AJORI B/article/view/856 